\title{
Karakteristik Kimia Minyak Ganitri (Elaeocoarpusganitrus ROXB) Hasil Ekstraksi
}

\section{Chemical Characteristics of Ganitri Oil (Elaeocoarpusganitrus Roxb) as an Extraction Results}

\author{
Santo Zeno Vinansius Sinuraya ${ }^{1)}$, Sarifah Nurjanah ${ }^{2)}$, Mimin Muhaemin ${ }^{3)}$ \\ ${ }^{1)}$ ProgramStudi Magister Teknologi Agroindustri, FTIP-UNPAD \\ 2) StafPengajar Program Studi Magister Teknologi Agroindustri, FTIP-UNPAD \\ 3) StafPengajar Program Studi Magister Teknologi Agroindustri FTIP-UNPAD \\ E-mail korespondensi : vinansiussinuraya@Gmail.com
}

\begin{tabular}{l} 
A R T I C LE IN F O \\
\hline Article history \\
Received: 18 Juni 2016 \\
Accepted: 22 Juli 2016 \\
Available online: Februari 2017 \\
\hline Keywords: \\
Ganitrus \\
Extraction \\
oil \\
chemicals \\
\hline
\end{tabular}

Kata kunci :

Ganitri

Ekstraksi

Minyak

Kimia

\begin{abstract}
A B S TRACT
Ganitri (ElaeocarpusganitrusRoxb) is a plant that is grown in Indonesia as shade trees. Ganitri seeds are produced in Indonesia, but not fully utilized. Ganitri beans from Indonesia are not yet widely known its chemical content, it is only used limited jewelry and trade. This study was conducted to determine the chemical content ganitri based on oil extraction process. The method used was completely randomized design and descriptive qualitative methods for chemical analysis of oil. The results showed that the oil ganitri has chemical content: 66,05\% FFA content, Iod number by 5,66, saponification of $38,42 \mathrm{mg} \mathrm{KOH} / \mathrm{g}$, acid number of $51,79 \%, 74.61 \%$ oil content and yield amounting to $47.84 \%$.
\end{abstract}

\begin{abstract}
A B S T R A K
Ganitri (Elaeocarpus ganitrus roxb) merupakan salah satu tanaman yang banyak ditanam di Indonesia sebagai pohon pelindung. Biji ganitri banyak dihasilkan di Indonesia, tetapi belum dimanfaatkan secara maksimal. Biji ganitri asal Indonesia belum banyak diketahui kandungan kimianya, sehingga baru dimanfaatkan sebatas perhiasan dan perdagangan. Penelitian ini dilakukan untuk mengetahui kandungan kimia minyak ganitri berdasarkan proses ekstraksi. Metode penelitian yang digunakan adalah rancangan acak lengkap dan metode deskriptif kualitatif untuk analisis kimia minyak. Hasil penelitian menunjukkan bahwa minyak ganitri memiliki kandungan kimia: kadar FFA sebesar 66,05 \%, bilangan Iodsebesar 5,66, bilangan Penyabunan sebesar 38,42 mg $\mathrm{KOH} / \mathrm{g}$, bilangan Asam sebesar 51,79\%, kadar minyak 74,61\%, dan rendemen sebesar $47,84 \%$.
\end{abstract}

\section{Pendahuluan}

Ganitri(Elaeocarpus Ganitrus) merupakan salahsatu tanaman kehutanan yang habitat aslinya berasal dari Negara subtropics dengan penyebaran yang cukup luas terutama di beberapa negara Asia Tenggara (Indonesia, Malaysia, Myanmar, dan Thailand), Madagaskar, CinaBagian Selatan, Nepal, Australia, dan kepulauan pasifik. Daerah penyebaran tanaman ganitri di Indonesia meliputi daerah Jawa Tengah, Kalimantan, Bali, dan Timor, dan tempat tumbuh tanaman ganitri berada pada ketinggian 500-1000 m dpl bahkan bias tumbuh pada ketinggian $1200 \mathrm{mdpl}$ (Sutarman, 2010).

TanamanGanitri(Elaeocarpusganitrusroxb) banyak tumbuh di Indonesia tetapi belum banyak dimanfaatkan oleh masyarakat.

Tanaman ini dikenal oleh masyarakat Indonesia dengan berbagai nama local yaitu Ganitri (Sunda), Katulampa, mataSiwa (Bogor), Sambung Susu (Jawa), Klitri (Madura), Biji Mala (Bali), BijiSima (Sulawesi Selatan).Di Indonesia tanaman Ganitri banyak ditanam di selatan pulau Jawa, Sumatera, Sulawesi Selatan, Bali, dan Kalimantan (Susilawati, 2012).
Di Indonesia biji ganitri selain bermanfaat sebagai pohon pelindung jalan raya (hutan kota), kayunya digunakan untuk pertukangan dan bahan baku alat musik (gitar, piano), selain itu bentuk dan ukuran biji ganitri yang unik dapat menghasilkan berbagai produk perhiasan (gelang, kalung, tasbih), bahkan di India dipergunakan sebagai bahan sesajen pada upacara pembakaran mayat (Heyne, 1987). Buah Ganitri berwarna biru dan berbentuk bulat, sedangkan biji ganitri memiliki kekhasan sendiri yaitu ornamen berbentuk garis tidak beraturan. Warna biji ganitri berbeda - beda tergantung dari kematangan dan bentuk buah, tetapi di domisili oleh warna coklat tua merah (gambar 1).

Di India Biji ganitri digunakan sebagai bahan baku obat herbal, sedangkan di Indonesia biji ganitri hanya dimanfaatkan sebagai produk perhiasan dan perdagangan. Melihat perbedaan dalam penggunaan biji gantiri, maka penelitian ini dilakukan untuk mengetahui kandungan kimia biji ganitri asal Indonesia. Berdasarkan kandungan kimianya suatu tanaman dapat dijadikan sebagai bahan baku industri. Biji ganitri Indonesia sampai saat ini belum dimanfaatkan sampai skala industri. Oleh karena itu dibutuhkan 
pengetahuan tentang kandungan kimia buah ganitri untuk mengetahui biji ganitri dapat dijadikan sebagai bahan baku industri. Tanaman dengan berbagai kandungan kimia di dalamnya menjadi tanaman yang menjanjikan sebagai sumber bahan baku industri(Vijayalakshmi and Ravindhran, 2012).

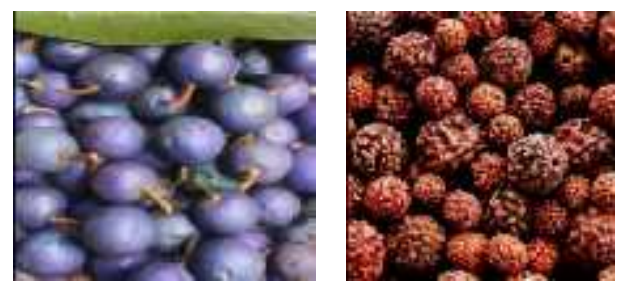

Gambar 1. Buah dan Biji Ganitri

\section{Metodologi}

Bahan dan Alat. Bahan baku yang digunakan untuk penelitian ini adalah kernel biji ganitri (Elaeocarpus ganitrus roxb) lokal yang diperolehdaripetani ganitri di Kebumen, Jawa Tengah dan fajar bulan, Lampung. Bahan kimia yang digunakan untuk analisis adalah $\mathrm{KOH}, \mathrm{CaCl}_{2}$, $\mathrm{NaOH}$, HClpekat, $\mathrm{HCl} 0,5 \mathrm{~N}$, Natrim Tiosulfat, Alkohol Netral, Heksan (Pa), Indikator PP, dan Amilum $1 \%$.

Peralatan yang digunakan untuk ekstraksi minyak adalah Extraction Soklet dan mesin pengepres hidraulik. Peralatan untuk analisis adalah beaker glass, spektroclorometer, mikropipet, kuvet, spektrofotometer UVVis, labuukur, sentrifuse, pH-meter, water bath, gelaspiala, termometer, heating mantle, erlenmeyer, danneracaanalitik.

\section{Analisis Kimia Minyak Ganitri.}

Analisis kimia minyak ganitri terdiri dari analisis proximat biji ganitri, analisis proximat kernel biji,bilangan asam, bilangan iod, kadar minyak, rendemen, dan kadar FFA

\section{Rancangan Percobaan.}

Penelitian ini dilakukan menggunakan metode rancangan acak lengkap dengan 2 perlakuan yaitu ekstraksi minyak secara mekanisasi dan sokletasi.

\section{Tahapan Ekstraksi Minyak Ganitri.}

Buah ganitri direndam dalam air selama 24 jam untuk memudahkan pengupasan kulit buah. Pengupasan kulit dan pembersihan buah ganitri dilakukan secara manual. Biji ganitri kemudian dikeringkan selama 7 hari dengan tujuan untuk memudahkan dalam pengambilan kernel biji. Pemecahan kulit biji dilakukan secara manual. Kernel biji ganitri kemudian ditepungkan dengan cara di grinder yang bertujuan untuk memaksimalkan hasil ekstraksi.Tahapa nekstraksi minyak dilakukan menggunakan metode mekanisasi (pengepresan biji) dan metode sokletasi (Ketaren,2008).

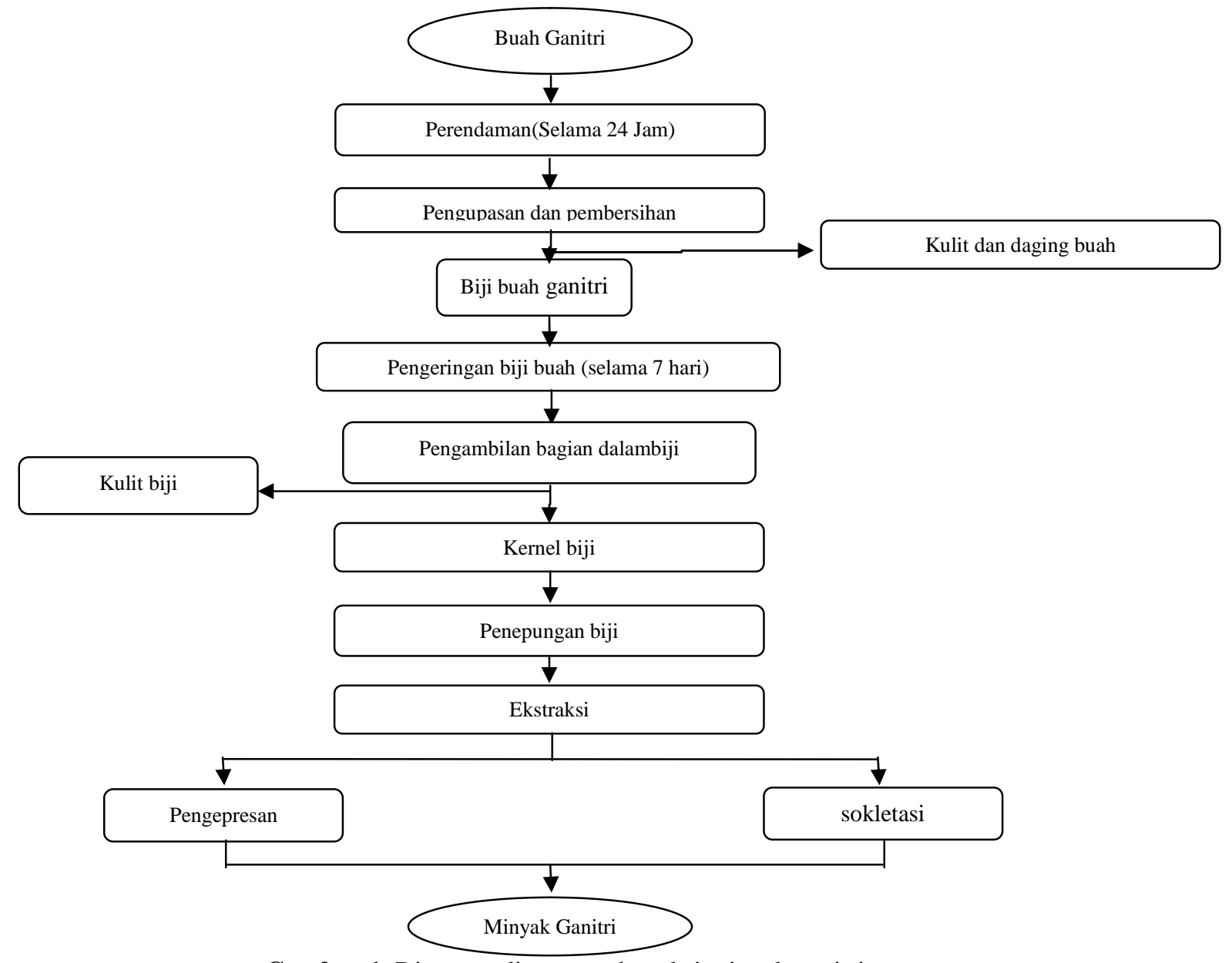

Gambar 1. Diagram alirproses ekstraksi minyak ganitri. 


\section{Hasil dan Pembahasan}

\section{Proximat Biji dan Inti Biji Ganitri.}

Analisis proximat biji dan inti biji ganitri dilakukan untuk mengetahui bagian biji atau inti biji yang akan dilakukan proses ekstrasi. Hasil analisis menunjukkan perbedaan kandungan senyawa kimia. Tabel 1 menunjukkan perbandingan komposisi kimia dalam biji dan inti biji ganitri.

Tabel 1. Kandungan Kimia Biji dan Inti Biji Ganitri

\begin{tabular}{lcc}
\hline \multicolumn{1}{c}{ Parameter } & Biji Ganitri & Inti Biji \\
\hline Kadar Air & 17,68 & 5,51 \\
Kadar Abu & 1,60 & 4,05 \\
Kadar Protein & 5,05 & 12,97 \\
Kadar Lemak & 12,87 & 66,41 \\
Kadar Karbohidrat & 62,8 & 11,06 \\
\hline
\end{tabular}

Kandungan kimia dalam biji didominasi oleh karbohidrat,sedangkan senyawa kimia dalam inti biji didominasi oleh lemak. Berdasarkan hasil analisis proximat yang ditunjukkan pada tabel di atas maka dilakukan proses ekstraksi minyak pada inti biji ganitri.

\section{Rendemen dan Kadar Minyak Ganitri.}

Minyak ganitri hasil ekstraksi secara mekanisasi dengan pengepresan memiliki rendemen minyak sebesar $22 \%$ dengan kadar minyak 74,69\%. Minyak ganitri hasil ekstraksi sokletasi dengan menggunakan heksan menghasilkan rendemen minyak sebesar 47,84\% dengan kadar minyak sebesar 74,61\%. Hasil ekstraksi dengan sokletasi menggunakan hexan memberikan hasil yang lebih tinggi daripada hasil ekstraksi secara mekanisasi. Hasil ekstraksi secara sokletasi yang lebih besar menggunakan pelarut heksan menunjukkan bahwa minyak ganitri hasil ekstraksi memiliki sifat netral atau non polar.

Bahan baku yang memiliki kandungan lemak/minyak non-polar dan diektraksi dengan menggunakan pelarut berjenis sama akan menghasilkan lebih banyak ketimbang menggunakan pelarut berjenis polar atau netral (Ketaren,2008).

\section{Kadar FFA (Free Fatty Acid).}

Kadar 'free fatty acids" (FFA) atau "asam lemak bebas" yaitu nilai yang menunjukkan jumlah asam lemak bebas yang ada di dalam lemak atau jumlah yang menunjukkan berapa banyak asam lemak bebas yang terdapat dalam lemak setelah lemak tersebut di hidrolisa (Ketaren, 2008).

Kandungan asam lemak bebas minyak ganitri hasil ekstraksi mekanisasi dan sokletasi sebesar 67,43\% dan $68,46 \%$. Menurut S Jain, K Jatwa, V Jain, A Sharma, SC Mahajan , (2014), kandungan asam lemak bebas minyak ganitri terdiri dari asam lemak palmitat dan linoleat.Kadar asam lemak bebas minyak ganitri yang cukup tinggi menunjukkan bahwa kandungan asam lemak bebas di dalam minyak cukup besar.
Kandungan FFA yang besar dalam minyak ganitri menunjukkan bahwa minyak ganitri dapat dijadikan sebagai bahan baku bioenergi dengan syarat kandungan FFA dalam minyak ganitri harus dikurangi hingga $1 \%$.

\section{Bilangan Asam.}

Bilangan asam dipergunakan untuk mengukur jumlah asam lemak bebas yang terdapat dalam minyak atau lemak. Bilangan asam minyak ganitri hasil ekstraksi secara mekanisasi sebesar 51,79, sedangkan hasil sokletasi sebesar 50,57. Nilai bilangan asam ini menunjukkan bahwa minyak ganitri memiliki kandungan asam lemak bebas yang cukup tinggi. Menurut Sudarmadji, 2003 semakin tinggi nilai bilangan asam, maka semakin rendah kualitasnya. Kualitas minyak yang rendah dapat disebabkan oleh kemurnian dan umur minyak yang digunakan (Ketaren,2008).

\section{Bilangan Iod.}

Bilangan iodium mencerminkan ketidakjenuhan asam lemak penyusun minyak dan lemak. Asam lemak tak jenuh mampu mengikat iod dan membentuk senyawa yang jenuh. Banyaknya iod yang diikat menunjukkan banyaknya ikatan rangkap. Lemak yang tidak jenuhdengan mudah dapat bersatu dengan iodium (dua atom iodium ditambahkan pada setiap ikatanrangkap dalam lemak). Semakin banyak iodium yang digunakan semakin tinggi derajat ketidakjenuhan. Biasanya semakin tinggi titik cair semakin rendah kadar asam lemak tidak jenuhdan demikian pula derajat ketidakjenuhan (bilangan iodium) dari lemak bersangkutan. Asamlemak jenuh biasanya padat dan asam lemak tidak jenuh adalah cair; karenanya semakin tinggibilangan iodium semakin tidak jenuh dan semakin lunak lemak tersebut (Sudarmadji,2007).

Minyak ganitri hasil ekstraksi mekanisasi memiliki bilangan iod sebesar 5,33 dan ekstraksi sokletasi sebesar 5,96 . Nilai bilangan iod minyak ganitri yang berada pada kisaran angka 5 sampai 6 menunjukkan bahwa minyak ganitri memiliki kandungan lemak tidak jenuh yang rendah dan titik cair yang rendah.

\section{Bilangan Penyabunan.}

Angka penyabunan menunjukkan berat molekul lemak dan minyak secara kasar. Minyak yang disusun oleh asam lemak berantai karbon yang pendek berarti mempunyai berat molekul yang relative kecil, akan mempunyai angka penyabunan yang besar dan sebaliknya bila minyak mempunyai berat molekul yang besar, maka angka penyabunan relative kecil. Angka penyabunan ini dinyatakan sebagai banyaknya (mg) $\mathrm{KOH}$ atau $\mathrm{NaOH}$ yang dibutuhkan untuk menyabun kan satu gram lemak atau minyak ( Ketaren, 2008).

Minyak ganitri hasil ekstraksi mekanisasi dan sokletasi memiliki nilai bilangan penyabunan masingmasing sebesar 25,45 mg KOH/gr dan 18,23 mg KOH/ gr. Nilai bilangan penyabunan minyak ganitri menunjukkan bahwa minyak ganitri memiliki rantai karbon panjang dan berat molekul yang besar. 


\section{Kesimpulan dan Saran}

\section{Kesimpulan}

Berdasarkan hasil penelitian kandungan kimia minyak inti biji ganitri terdiri dari: kadar lemak $66,41 \%$, kadar air 5,51\%, kadar abu 4,05\%, kadar protein 12,97, kadar karbohidrat $11,06 \%$. Sedangkan kandungan kimia minyak biji ganitri terdiri dari: kadar lemak 12,87\%, kadar air $17,68 \%$. Kadar abu 1,60\%, kadar protein 5,05\%, dan kadar karbohidrat $62,8 \%$.

Kandungan kimia minyak inti biji ganitri didominasi oleh lemak, sedangkan pada biji didominasi oleh karbohidat, sehingga ekstraksi minyak dilakukan pada inti biji.

Berdasarkan hasil penelitian ekstraksi sokletasi menghasilkan rendemen minyak lebih besar daripada ekstraksi hasil pengepresan, tetapi memiliki kandungan kimia dan kadar minyak yang hampir sama.

\section{Saran}

Perlu dilakukan penelitian-penelitian selanjutnya untuk mengetahui penggunaan minyak ganitri.

\section{Daftar Pustaka}

Heyne, K. 1987. Tumbuhan Berguna Indonesia. Jilid 3. Kementerian Kehutanan. Jakarta.

Ketaren, S. 2008. Pengantar Teknologi Pangan: Minyakdan Lemak. UI-Press. Universitas Indonesia. Jakarta.

Sudarmadji. S. 2007. Analisis bahan makanan dan pertanian. Liberty. Yogyakarta

Sutarman, A. 2010. Mengenal Tanaman Jenitri (Elaeocarpus Sphaericus Schum). Badan Penyuluhan dan Pengembangan Sumber Daya Manusia Pertanian. Kementerian Pertanian. http://cybex.deptan.go.id/penyuluhan/mengenaltanaman-jenitri-elaeocarpus-sphaericus-schum. Diakses pada tanggal 2 Mei 2014.

S Jain, K Jatwa, V Jain, A Sharma, SC Mahajan; A Review on Elaeocarpus Sphaericus (Rudraksha); PharmaTutor; 2014; 2(7); 83-91

Vijayalakshmi, R. and R. Ravindhran, 2012. Preliminary Comparative Phytochemical Screening Of Root Extracts Of Diospyrus Ferrea(Wild.) Bakh and Aerva lanata (L.) juss. Ex Schultes. Asian J. Plant Sci.Res., 2: 581-587. 